\title{
Problemy przekładu specjalistycznego na przykładzie tekstów z dziedziny prawa, biologii, biotechnologii i medycyny
}

\section{Problems of specialist translations on examples of texts from domains like biology, biotechnology and medicine}

\author{
Patrycja Kłos; Aleksandra Matulewska; Paulina Nowak-Korcz. \\ Instytut Językoznawstwa, Uniwersytet im. Adama Mickiewicza \\ ul. Międzychodzka 5, 60-371 Poznań
}

\begin{abstract}
paulina.nowak@gmail.com; aleksandra.matulewska@gmail.com
\end{abstract}
\begin{abstract}
This article deals with the analysis of problems in translation of EU directives from English into Polish. The examples were taken from three directives regulating medicine, biology and biotechnology-related matters. The authors have discussed the translation problems and classified mistakes and errors identified in the Polish-language versions and have given their translation suggestions. A short description of characteristic features of selected problems has been given. The authors also discuss the main roots of problems occurring in translations of texts formulated in more than one LSP.
\end{abstract}

\section{Wstęp}

Niniejszy artykuł dotyczy problemów związanych z przekładem tekstów specjalistycznych z języka angielskiego na polski, a konkretnie tekstów z dziedziny biologii, biotechnologii i medycyny. Omawiane przykłady problemów tłumaczeniowych zostały zaczerpnięte $\mathrm{z}$ podręcznika biotechnologii autorstwa Brostoffa i Gamlina pt: Food allergies and intolerance, w dwóch wersjach językowych: angielskiej i polskiej (pt.: Alergia $i$ nietolerancja pokarmowa) oraz $\mathrm{z}$ tekstów niżej wymienionych dyrektyw unijnych:

$>$ Directive 2003/89/EC of the European Parliament and of the Council of 10 November 2003 amending Directive 2000/13/EC as regards indication of the ingredients present in foodstuffs (Text with EEA relevance) - (Dyrektywa 2003/89/WE Parlamentu Europejskiego i Rady z dnia 10 listopada 2003 r. zmieniająca dyrektywę 2000/13/WE w odniesieniu do oznaczania składników obecnych w środkach spożywczych);

$>$ Commission directive 2001/36/EC of 16 May 2001 amending Council directive 91/414/EEC concerning the placing of plant protection products on the market (Dyrektywa Komisji 2001/36/WE z dnia 16 maja 2001 r. zmieniająca dyrektywę Rady 91/414/EWG dotyczącą wprowadzania do obrotu środków ochrony roślin);

$>$ Directive 2000/54/EC of the European Parliament and of the Council of 18 September 2000 on the protection of workers from risks related to exposure to biological agents at work (seventh individual directive within the meaning of Article 16(1) of Directive 89/391/EEC) - (Dyrektywa 2000/54/WE Parlamentu Europejskiego i Rady z dnia 18 
września 2000 r. W sprawie ochrony pracowników przed ryzykiem związanym z narażeniem na działanie czynników biologicznych w miejscu pracy).

\section{Problemy przekładu specjalistycznego}

Nabokov (2002) mówiąc o przekładzie twierdzi, że tłumacz „Przede wszystkim musi mieć taki sam talent, a przynajmniej podobny typ talentu, jak autor, którego wybiera sobie do tłumaczenia. (...) Po drugie, tłumacz musi znać doskonale dwie nacje i dwa języki, z jakimi będzie miał do czynienia, i wiedzieć absolutnie wszystko, w najdrobniejszych szczegółach, o stylu, metodzie pisarskiej tłumaczonego autora, a także o «społecznym» kontekście słów, ich etymologii, ewolucji i historycznych odniesieniach. Tu dochodzimy do punktu trzeciego: będąc człowiekiem wielkiego talentu i wiedzy, tłumacz musi mieć także umiejętność mimikry, to znaczy zdolność utożsamienia się z osobą autora, przyswojenia sobie jego wszystkich trików, jego maniery i języka, nawyków i sposobu myślenia, i to w takim stopniu, aby osiagnąć jak największą wiarygodność". Podobnie nierealistyczne założenia przedstawia Mona Baker, mówiąc o wykształceniu tłumacza tekstów specjalistycznych. Założenia Nabokowa są bardzo szczegółowe i zarazem dla większości tłumaczy niemożliwe do spełnienia.

Problemy związane z przekładem specjalistycznym również wynikają ze stereotypowego podejścia do zawodu tłumacza. Za taką sytuację należy częściowo obwinić niezbyt udane Rozporządzenie MINISTRA SPRAWIEDLIWOŚCI z dnia 8 czerwca 1987 r. w sprawie biegłych sądowych i thumaczy przysięgłych. (Dz. U. z dnia 23 czerwca 1987 r.). Zgodnie z tym Rozporządzeniem głównym sposobem weryfikacji kompetencji tłumacza przysięgłego był wymóg posiadania dyplomu ukończenia właściwie tylko studiów filologicznych. Rozporządzenie, bowiem określało, co następuje:

§ 17. Thumaczem języka obcego może być ustanowiona osoba, która:

1) posiada obywatelstwo polskie i korzysta z pełni praw cywilnych i obywatelskich,

2) ukończyła 25 lat życia,

3) wykaże odpowiednią znajomość języka polskiego i języka obcego, dla którego ma być ustanowiona thumaczem, oraz umiejętność tłumaczenia,

4) daje rękojmię należytego wykonywania obowiązków thumacza,

5) ukończyła wyższe studia magisterskie,

6) wyrazi zgodę na pełnienie funkcji thumacza.

§ 18. 1. Znajomość języka obcego oraz umiejętność tłumaczenia powinna być wykazana dyplomem ukończenia i uzyskaniem tytułu zawodowego magistra odpowiednich dla danego języka wyższych studiów filologicznych lub studiów w zakresie lingwistyki stosowanej.

2. Znajomość języka obcego oraz umiejętność tłumaczenia może być za zgodą Ministra Sprawiedliwości wykazana również dyplomem lub świadectwem innym niż wymienione w ust. 1 albo stwierdzona w inny sposób.

3. Przepis ust. 2 stosuje się odpowiednio do wykazania znajomości języka polskiego.

W ten sposób ustawodawca ograniczył grono osób mogących ubiegać się się o pracę thumacza przysieggego tylko i wyłącznie do absolwentów konkretnych filologii. Pozostali potencjalni kandydaci, niespełniający tego wymogu, mimo posiadanych umiejętności, nie mogli wcale się ubiegać o takie stanowisko. Sytuacja komplikowała się dodatkowo, gdyż właściwie każdy sąd miał własne kryteria naboru tłumaczy. W mniejszych miejscowościach przyjmowano tylko na podstawie złożonych dokumentów, w większych miastach przeprowadzano egzaminy sprawdzające praktyczne umiejętności kandydatów. Jednocześnie wykształcił się stereotyp wśród społeczeństwa, iż tłumaczem może być tylko osoba wykonująca zawód thumacza przysięgłego. Jeżeli ktoś nie mógł być tłumaczem przysięgłym, stawał się w oczach społeczeństwa thumaczem gorszej kategorii, niewykwalifikowanym robotnikiem. $Z$ niezrozumiałych przyczyn ustawodawcy trudno jest zrozumieć, iż nie każdy absolwent filologii angielskiej jest odpowiednim kandydatem na tłumacza, zwłaszcza przysięgłego. Agencje tłumaczeniowe często popełniają ten sam błąd. Zatrudniaja nie tyle osoby posiadające odpowiednie kompetencje, co osoby posiadające odpowiednie papiery. 
Mimo, iż rozporządzenie zostało zastapione ustawą z dnia 25 listopada 2004 r. o zawodzie thumacza przysięgłego (Dz. U. Nr 273, poz. 2702) ${ }^{1}$ w dalszym ciągu trudno stwierdzić czy możemy liczyć na znacząca poprawę kwalifikacji tłumaczy. Jedyne co się znacząco zmieniło to, to iż osoby nie będące absolwentami filologii mogą starać się o stanowisko thumacza przysięgłego o ile ukończą studia podyplomowe w zakresie thumaczenia. Ponadto wszyscy kandydaci mają być egzaminowani w zakresie umiejętności tłumaczenia. $\mathrm{W}$ dalszym ciągu nie jest doprecyzowane $\mathrm{w}$ jaki sposób sprawdzać znajomość języka polskiego (a przecież tłumacze Konstytucji Europejskiej z całą pewnością mieli braki w zakresie języka polskiego o czym świadczy tak częste naruszanie związku rządu i fatalny styl tłumaczenia).

Dużo bardziej realistycznie do problemu kompetencji tłumacza tekstów specjalistycznych pochodzi Kodeks Tłumacza Przysięgłego, który nie mówi o tym jakie studia tłumacz powinien ukończyć, ale kładzie nacisk na kompetencje, umiejętności i chęć ustawicznego dokształcania się. Tłumacz przysięgły ma być osobą, która świetnie zna język ojczysty, obcy, zna języki specjalistyczne, z których teksty tłumaczy, zna kulturę i rzeczywistość prawną języka docelowego i źródłowego.

Gdy tłumacz spełni wymogi formalne musi zmierzyć się z problemem samego procesu przekładowczego. W rozwiązywaniu problemów thumaczeniowych pomocą służą strategie i procedury (metody) thumaczeniowe. Delisle (1999:192) definiuje strategie thumaczeniowe jako ,a coherent plan of action adopted by translators based on their intention with respect to a given text." Procedura thumaczeniowa jest natomaist metodą stosowaną przez thumaczy w trakcie procesu zapewnania ekwiwalencji thumaczeniowej „for the purpose of transferring elements of meaning from the source text to the target text" (Delisle 1999:191). Przekład języków specjalistycznych jest uważany za całkowicie odmienny od przekładu artystycznego. Co więcej dyrektywy unijne analizowane przez autorki są tak naprawdę jednocześnie sformułowane w dwóch językach specjalistycznych tzn. jako akty normatywne UE są one napisane w języku prawnym, który Wróblewski (1948) definiuje jako język, którym posługuje się ustawodawca pisząc ustawy, rozporządzenia, dyrektywy, etc. Ponadto regulują one jaką́s inną niż prawo dziedzinę tzn. zawierają odpowiednio elementy języka biologii, biotechnologii lub medycyny. Pojawia się tu problem czy jest zatem możliwe przetłumaczenie tekstu sformułowanego w więcej niż jednym języku specjalistycznym, czy też czy jest możliwe znalezienie tłumacza znającego więcej niż jeden język specjalistyczny na poziomie umożliwiającym przekład takich tekstów. Jak słusznie zauważa Pieńkos (1999:119) „Aby określić specyfikę przekładu tekstów prawnych i prawniczych, należy przede wszystkim przyjąć założenie, że przekład jest możliwy. W tym celu są dla nas nie do przyjęcia argumenty niektórych teoretyków przekładu, w tym językoznawców, dla których identyczność, czyli doskonała równość matematyczna słów i wyrażeń oraz naturalnie pojęć, które one reprezentuja, jest niemożliwa do uzyskania, jeżeli chce się przejść od jednego kodu językowego do drugiego. Zamiast identyczności - pojęcia matematycznego i abstrakcyjnego przyjmuje się w przekładzie zasadę ekwiwalencji sytuacji, a zatem środków szczególnych, którymi dysponuje każdy język dla ich opisania, niezależnie od tego, czy będzie ona ekwiwalencją dynamiczną, formalną czy inną. Jeśli chodzi o działalność przekładową dotyczącą tekstów

\footnotetext{
${ }^{1}$ Art. 2. 1. Tłumaczem przysięgłym może być osoba fizyczna, która:

1) ma obywatelstwo polskie albo obywatelstwo jednego z państw członkowskich Unii Europejskiej, państw członkowskich Europejskiego Porozumienia o Wolnym Handlu (EFTA) - stron umowy o Europejskim Obszarze Gospodarczym lub, na zasadach wzajemności, obywatelstwo innego państwa;

2) zna język polski;

3) ma pełną zdolność do czynności prawnych;

4) nie była karana za przestępstwo umyślne, przestępstwo skarbowe lub za nieumyślne przestępstwo przeciwko bezpieczeństwu obrotu gospodarczego;

5) ukończyła magisterskie studia wyższe na kierunku filologia lub ukończyła magisterskie studia wyższe na innym kierunku i studia podyplomowe w zakresie thumaczenia, odpowiednie dla danego języka;

6) złożyła z wynikiem pozytywnym egzamin z umiejętności tłumaczenia z języka polskiego na język obcy oraz z języka obcego na język polski, zwany dalej "egzaminem na tłumacza przysieggłego".
} 
prawnych i prawniczych, opowiadamy się za ekwiwalencją funkcjonalna, najbardziej przydatną i skuteczną dla tego rodzaju przekładu". Wiele trudności związanych z przekładem wynika również z nieprzystawalności rzeczywistości i aparatu terminologicznego używanego przez użytkowników danego języka. Co więcej specyfika aktów normatywnych również wpływa na proces przekładu i w konsekwencji może prowadzić do powstawania brzemiennych w skutki błędów.

Najogólniej można stwierdzić, ze tłumacze tekstów sformułowanych w językach specjalsitycznych powinni pamiętać o trzech zasadach sformułowanych przez Tytlera (1813:9) które do tej pory nie straciły nic ze swej aktualności. Tytler mówiąc o przekładzie stwierdza mianowicie:

„I. That the Translation should give a complete transcript of the ideas of the original work.

II. That the style and manner of writing should be of the same character with that of the original.

III. That the Translation should have all the ease of original composition."

Do najlepszych strategii thumaczeniowych mających zastosowanie do przekładu tekstów specjalistycznych można zaliczyć teorię skoposu Vermeera. Vermeer (2001: 230) twierdzi, że „a translatum is not ipso facto a «faithful» imitation of the source text. «Fidelity» to the source text (...) is one possible and legitimate skopos or commission”. A nastepnie dodaje (2001: 231) „the skopos theory thus in no way claims that a translated text should ipso facto conform to the target culture behaviour or expectations, that a translation must always «adapt» to the target culture. This is just one possibility: the theory equally well accommodates the opposite type of translation, deliberately marked, with the intention of expressing source-culture features by target-culture means. Everything between these two extremes is likewise possible, including hybrid cases. To know what the point of a translation is, to be conscious of the action - that is the goal of the skopos theory".

Tłumaczenie tekstów specjalistycznych to zadanie złożone. Tłumacze tego rodzaju tekstów codziennie borykają się z problemami, które wielokrotnie są przyczyną powstawania błędów thumaczeniowych, niekiedy nawet skandalicznych. Problemy thumaczeniowe mogą mieć różnorodny charakter i mogą być wynikiem działania wielu czynników. Mogą wynikać z nieodpowiedniej wiedzy na temat zasad przekładu, czy też z braku odpowiedniej metody przekładowej. Problemy tłumaczeniowe są niekiedy efektem niewiedzy tłumacza na poziomie językowym lub na poziomie znajomości dziedziny, do której należy tekst wyjściowy. Błędy tłumaczeniowe mogą być wynikiem działania wieloznaczności językowej tj: wieloznaczności polisemicznej, homonimicznej czy też synonimii. Ponadto, terminy bezekwiwalentowe też są częstą przyczyną powstawania błędów. W praktyce okazuje się, że niestety nie każdy tłumacz zna metody zapewniania ekwiwalencji dla terminów bezekwiwalentowych, co w konsekwencji prowadzi do powstawania błędów. Nie każdy tłumacz jest również świadomy niebezpieczeństw wynikających ze zjawiska interferencji, zarówno zewnętrznej jak i wewnętrznej, prowadzącej do licznych błędów w przekładzie. Odrębnym problemem jest natomiast brak znajomości dziedziny oraz języka tej dziedziny. Należy przy tym podkreślić, że warunkiem koniecznym do wykonania dobrego tłumaczenia specjalistycznego jest przede wszystkim znajomość dziedziny, do której należy tłumaczony tekst. Kolejną przyczyną powstawania błędów w przekładzie jest niewystarczająca znajomość języka obcego, jak również języka ojczystego. Niedostateczna znajomość morfologii, składni, stylistyki, leksyki, a szczególnie semantyki i ortografii obu języków, to poważny problem w trakcie thumaczenia tektów nie tylko specjalistycznych. Brak wiedzy z zakresu podstawowych zasad formułowania tekstów ustawowych w języku polskim (ZTP, Dz. U. z 2002 r. Nr 100, poz. 108) stanowi również poważna przeszkodę w procesie tłumaczenia teksów specjalistycznych. Ponadto, błędy przekładu specjalistycznego są niekiedy efektem nieznajomości teorii i strategii przekładu tekstów specjalistycznych.

Kolejną istotną kwestia, która zdaje się wpływać na jakość thumaczeń jest brak odpowiedzialności tłumacza. Tłumacz w Polsce do tej pory nie musiał się obawiać konsekwencji związanych ze źle dokonanym przekładem. Nie ponosił odpowiedzialności ani cywilnej, ani karnej. Dlatego wiele osób brało się do wykonywania tego zawodu, a ryzyko było zerowe. Obecnie sytuacja ta się powoli zmienia. Coraz częściej słyszy się o klientach, którzy ponieśli straty w związku ze źle dokonanym przekładem i pozywają tłumacza do sądu. W związku z tym, może 
też niekompetentnych chętnych do wykonywania tego zawodu będzie trochę mniej, a jakość tłumaczeń się nieco poprawi.

\section{Problemy thumaczeniowe wynikające $z$ wieloznaczności językowej}

Wiele wyrazów w języku polskim, podobnie jak i w innych językach to wyrazy wieloznaczne. Powoduje to wiele problemów thumaczeniowych. Jak zauważa Grucza (1999: 3): „Źródłem tych trudności są też różne deficyty w zakresie potencjału komunikacyjnego poszczególnych języków: Wszystkie języki ludzkie są pod niejednym względem ułomne. Wiadomo, że nie jest łatwo wyrażać się w nich jednoznacznie, że w wielu wypadkach nie jest to w ogóle możliwe. Bardzo często nie udaje się to nawet autorom tekstów naukowych. Bardzo wiele kłopotów jednoznaczność sprawia też autorom tekstów legislacyjnych. Nawet, jeśli bardzo się o nią starają, w rzeczywistości osiagaja ją rzadko. $Z$ reguły jest tak, że w danym języku do dyspozycji mówcy/pisarza, a tym samym także translatora, stoi z jednej strony więcej niż jedna możliwość wyrażeniowa (wyraz, kategoria gramatyczna, struktura składniowa, itd.), z drugiej natomiast żaden adekwatny środek wyrażeniowy. W pierwszym przypadku translator musi dokonać twórczego wyboru, $\mathrm{w}$ drugim natomiast musi sam wykreować odpowiedni środek wyrażeniowy lub zaadoptować obcy. Natomiast w tego rodzaju sytuacji jak ta, w której znajdujemy się aktualnie, tzn. w sytuacji lawinowego importu różnych zachodnich „dóbr” ideowych (politycznych, ekonomicznych, administracyjnych, strukturalnych, kulturowych) i materialnych, translator jest zmuszony wykonywać pracę o charakterze kreatywnym w znacznie wyższym stopniu niż w świecie już $\mathrm{w}$ miarę zarówno ideowo, jak i materialnie zrównoważonym". Zieliński (2006: 146) wyróżnia dwa rodzaje wieloznaczności: wieloznaczność polisemiczną i wieloznaczność homonimiczną. „Polisemia polega na tym, że jeden termin ma kilka znaczeń i to znaczeń, które w jakiś sposób nawet daleki - wiążą się ze sobą. Na przykład (...) wyraz «dom» ma siedem znaczeń. W pierwszym znaczy tyle, co «budynek przeznaczony na mieszkanie, pomieszczenie instytucji itp.», $\mathrm{w}$ drugim znaczy tyle co «mieszkanie, pomieszczenie mieszkalne, miejsce stałego zamieszkania, własny kąt». Znaczenia te mają ze sobą jakiś określony związek" (Zieliński 2006: 146). Podobnie uważa Polański (1999: 288), który podkreśla, że „polisemia (wieloznaczność) polega na tym, iż jakiś element językowy (wyraz, morfem) ma dwa lub kilka różnych znaczeń. Wyrazy (morfemy, konstrukcje syntaktyczne) posiadające tę właściwość nazywamy polisemicznymi (wieloznacznymi)". Zjawisko polisemii jest często szeroko omawiane przez teoretyków thumaczenia.Trudność w tym przypadku polega na tym, że ,jeden leksem może odsyłać do wielu konceptów (znaczeń), ale nie koniecznie $\mathrm{w}$ ten sam sposób w różnych językach (Pisarska, Tomaszkiewicz 1996: 92). Przykładowo termin jeść może oznaczać jedzenie jako proces (manger, eating, essen) jak również jedzenie jako przedmiot (la nourriture, food, das Essen). Zjawisko polisemii występuje we wszystkich językach, jednakże nie ma „,...) odpowiedników pól semantycznych między jednostkami leksykalnymi różnych języków..." (Pisarska, Tomaszkiewicz 1996: 94). Dlatego też, tłumacze nieustannie borykają się $z$ problemami tłumaczeniowymi wynikającymi z polisemii. Przykładami ilustrującymi problemy wynikające z tego zjawiska są: (i) nieregularności w kombinacjach słownych (np.: gotować mięso i gotować zupe to po francusku faire bouillir de la soupe i faire cuir de la viande natomiast $\mathrm{w}$ języku angielskim kombinację sa również inne: przykładowo gotować kolację to: cook dinner ale gotować wodę to: boil water); (ii) brak odpowiedniości jednostek leksykalnych np.: rodzeństwo występujące w języku niemieckim jako Geschwister, dla którego ani w języku angielskim, ani we francuskim nie ma jednowyrazowego odpowiednika (franc. frères et soeurs; ang. brothers and sisters). „Ekwiwalencja leksykalna jeżeli nawet istnieje, prawie zawsze jest przybliżona i prawie nigdy nie jest absolutna" (Pisarska, Tomaszkiewicz 1996: 95).

Polański zwraca uwagę, że zjawisko polisemii często trudno odgraniczyć od homonimii. Homonimia według Polańskiego (1999: 136) „polega na wyrażaniu różnych znaczeń za pomoca identycznej formy językowej". Homonimia może wystąpić w składni (np.: zdrada przyjaciela oznacza fakt, iż przyjaciel zdradził, lub że został zdradzony), w morfologii (fleksyjnej np.: dam może być zarówno formą czasownika dać, jak również dopełniaczem liczby mnogiej rzeczownika dama oraz słowotwórczej np.: ranny pochodzące od słowa rana i rano), w słownictwie (np.: rola 
(aktora) i rola (uprawna); zamek (u drzwi) i zamek (na wzgórzu) (Polański 1999: 136). Zieliński (2006: 146) analizując wieloznaczność bazy leksykalnej języka tekstów prawnych nazywa homonimami „te zwroty wieloznaczne, w przypadku których różne znaczenia przypisywane temu samemu terminowi nie mają ze sobą nawet dalekiego związku. Słowo koza w znaczeniu zwierzęcia nie ma zbyt wiele wspólnego ze słowem koza w znaczeniu ławki bednarskiej, czy też przyrządu do suszenia koniczyny, jak również miejsca odosobnienia. Ponadto na uwage zasługuje również zjawisko synonimii. Synonimia ,polega na wyrażaniu tej samej treści za pomocą dwu (kilku) różnych form językowych" (Polański 1999: 385). Synonimia może występować w konstrukcjach składniowych (np.: rzucić kamieniem - rzucić kamień), w formach morfologicznych (inżynierowie - inżynierzy), w leksemach (lingwistyka - językoznawstwo; pojazd - wehikut). Synonimia wielokrotnie prowadzi do powstawania licznych błędów w przekładach tekstów specjalistycznych.

Ta wieloznaczność wyrazów nie ma większego znaczenia i nie jest przeszkodą w komunikowaniu się, ponieważ wyrazy te pojawiają się zwykle na tle pewnego kontekstu i $\mathrm{w}$ określonej sytuacji, co daje wystarczającą ilość informacji, aby zorientować się, które ze znaczeń ma na myśli piszący czy też rozmówca (Kurkowska, Skorupka 2001: 137). Problem pojawia się natomiast „,...) w stylu naukowym, w wypowiedziach oficjalnych, wszędzie tam, gdzie chodzi o terminologię naukową i techniczną, wieloznaczność wyrazów jest niepożądana i często jest przyczyną powstawania błędów" (Nowak 2006: 184). Dzierżanowska (1990: 90) podkreśla, że „wyrazy w jednym języku, rzadko są pełnymi ekwiwalentami wyrazów w innymi języku, a zakres ich znaczeń może być zarówno szerszy jak i węższy". Należy tutaj podkreślić, że tłumacze, zwłaszcza tekstów specjalistycznych, należących do takich dziedzin jak: medycyna, biotechnologia czy prawo, którzy korzystają z bazy leksykalnej, w dużej mierze złożonej $\mathrm{z}$ terminów wieloznacznych powinni być szczególnie wyczuleni na tego typu wyrazy oraz dążyć do zachowania jednoznaczności językowej. „Czasem kontekst aktualizuje sens, który staje się jednoznaczny, czasem wieloznaczność jest zamierzona przez autora jako pewien zabieg stylistyczny (często stosowany w sloganach reklamowych, grach słownych). Jeżeli zatem efekt ten jest zamierzony, to trudność przekładu polega na osiągnięciu tej samej wieloznaczności w tekście docelowym. Natomiast jeżeli thumacz poprzez dobór środków językowych wprowadził wieloznaczność do przekładu, w którym efekt ten nie był zamierzony przez autora, to jest to błąd" (Pisarska, Tomaszkiewicz 1996: 151).

W analizowanych tekstach z dziedziny biologii, biotechnologii i medycyny wieloznaczność językowa doprowadziła do powstania następujących błędów tłumaczeniowych: Przykład 1.

- W tekście angielskim, termin: dermal sensitisation, został przetłumaczony jako: uczuleń dermalnych, a powinien zostać przetłumaczony jako: uczuleń skórnych. W tym przypadku nie doszło do zmiany znaczenia, ponieważ znaczenie można wydedukować. Niemniej jednak, w tym przypadku, mamy doczynienia z nieuzasadnionym stworzeniem terminu synonimicznego dermalny kiedy bardziej odpowiednim w tym przypadku jest termin Przykład 2. skórny. Jest to również zbędne zapożyczenie w postaci kalki.

- W tekście angielskim, termin: sensitisation by inhalation, przetłumaczono jako: uczulenie inhalacyjne, a powinno zostać przetłumaczone jako: uczulenie wziewne. Podobnie jak powyżej, nie doszło tutaj do zmiany znaczenia, znaczenie również może być odkodowane, natomiast błąd polega na nieuzasadnionym utworzeniem synonimu. Jednocześnie, jest to Przykład 3. zapożyczenie w postaci kalki.

- W tekście angielskim termin: irritation, przetłumaczono na język polski jako: właściwości podrażniajace, zamiast: właściwości drażniace. Nie ma w tym przypadku zmiany znaczenia. Błąd w tym przypadku wiąże się natomiast $\mathrm{z}$ nieuzasadnionym zastosowaniem synonimu.

Przykład 4.

- W tekście angielskim wystapił termin: cytomegalovirus, w polskim tłumaczeniu natomiast jest: Wirus Cytomegalo, a powinno być: wirus cytomegalii/cytomegalowirus. Brak zmiany 
znaczenia. Znaczenie można wydedukować z kontekstu. Tłumacz stworzył niepotrzebny byt o charakterze synonimicznym dla terminu już istniejącego w języku polskim.

\section{Problemy wynikające $z$ nieznajomości dziedziny (oraz terminologii tej dziedziny) lub braku ekwiwalentów w języku docelowym (terminologia i frazeologia)}

Znajomość przedmiotu i dziedziny (oraz terminologii), do której należy thumaczony tekst jest bardzo istotna $\mathrm{w}$ procesie thumaczenia tekstu specjalistycznego. Według Pieńkosa (2003: 234) „Tekst specjalistyczny wymaga od thumacza znajomości danej dziedziny oraz zasad, rządzących sztuką przekładu. Znajomość terminologii zastosowanej $\mathrm{w}$ danej dziedzinie wiedzy lub thumaczonym dziele naukowym jest - obok gruntownej znajomości języka oryginału i języka przekładu - jednym $\mathrm{z}$ podstawowych warunków osiąnięcia równowartościowego $\mathrm{i}$ pełnowartościowego przekładu dzieła. (...) Tłumacza dzieła naukowego czy tekstu profesjonalnego obowiązuje gruntowna znajomość terminologii i zakresów semantycznych terminów, którymi posługuje się dana dziedzina wiedzy lub autor dzieła". Należy jednak pamiętać, że nie zawsze wyrazy należące do jednego języka pokrywają się znaczeniowo $\mathrm{z}$ wyrazami należącymi do drugiego języka. Dzierżanowska (1990: 90), opisując niezgodność leksykalną na poziomie wyrazów i grup wyrazowych podkreśla, że „wyrazy w jednym języku rzadko są pełnymi ekwiwalentami wyrazów w innym języku, a zakres ich znaczeń może być zarówno szerszy jak i węższy". Każda dyscyplina naukowa posiada własną terminologię, a tłumacz musi jej przestrzegać. Błędy terminologiczne polegają głównie na użyciu wyrazów w niewłaściwym znaczeniu lub w zniekształconej postaci, albo też na użyciu wyrazu, który nie należy do zasobu polskiego słownictwa. Różnice terminologiczne są częstą przyczyną powstawania błędów i wiążą się $\mathrm{z}$ brakiem znajomości terminologii języka specjalistycznego u thumacza. Dzierżanowska (1990:96) podkreśla, że „Z istnienia tych różnic thumacz musi zdawać sobie sprawę, szczególnie że słowniki nieraz zawodzą i w takim przypadku trzeba odwołać się do wiedzy ekspertów w danej dziedzinie, a nie polegać wyłącznie na informacjach zaczerpniętych z publikacji słownikowych". Według Dzierżanowskiej (1990: 96) „błędy w terminologii powstają na ogół na skutek użycia wyrazu właściwego dla kultury języka orygiału, a nie używanego w tym sensie w TL". Pieńkos (2003: 229), pisząc o terminologii tekstów specjalistycznych, wyróżnia trzy rodzaje terminów. Istnieją zatem terminy, które mają odpowiednik semantyczny w języku obcym (np.: ang. offer, fr. offre, pol. oferta). Występują jednak też takie terminy, które nie mają dokładnego odpowiednika, lecz dla których można znaleźć odpowiednik funkcjonalny (np.: ang. mortgage, fr. hypothèque, pol. hipoteka). Z kolei Joseph (1995:23) stwierdza, że „translation is generally possible because in everyday language words, their component parts, their order, and most importantly their meanings are not like fixed points, but fuzzy blots at best. While the blots of L1 may rarely correspond exactly to those of L2, chances are that their fuzz will overlap enough for most translation purposes. Literary translation, especially the translation of poetry, exploits those fuzzy areas to the fullest. But law, or at least some areas of it, requires those blots to shed their fuzz and become point-like; and indeterminacy resides in the difficulty we have in making language do this with any consistency". Ponadto, istnieją terminy, które są niemalże nieprzekładalne (np.: ang. common law, fr. équité). W przypadku terminów nieprzekładalnych, które niekiedy bywają nazywane bezekwiwalentowymi (Kierzkowska 2002), istnieje wiele technik zapewniania ekiwalencji. Wprowadzenie do nauki o przekładzie terminu ekwiwalencja zawdzięczamy Jakobsonowi. Pod pojęciem termin bezekwiwalentowy będziemy rozumieć w niniejszym artykule taki termin, który nazywa byt istniejący w rzeczywistości języka źródłowego, ale nieistniejący w rzeczywistości języka docelowego. Smith (1995: 187) zauważa, że brak ekwiwalentu jest jedną z głównych trudności napotykanych przez thumaczy i dlatego „recognizing a case of absent terminology requires constant comparison between the legal systems of the source and the target languages, as well as being familiar with up-to-date legal literature. (...) «equivalency» refers to equal value between source and target text, and «adequacy» concerns partial dimensions of the text". W przypadku braku ekwiwalentów w języku docelowym thumacz ma do wyboru wiele strategii thumaczeniowych, pozwalających zapewnić odpowiedni ekwiwalent dla terminu bezekwiwalentowego (Kierzkowska 1991; Vinay, Darbelnet 1958; Varó, Hughes 2002). 
Vinay i Darbelnet opracowali siedem typów strategii translatorskich, do których zaliczyli:

a) zapożyczenia np.: chargé d'affaires, acquis communautaire; czy też: departament, dystrykt, kanton, dyrektoriat, konstytuanta, komuna, mer, zyrondysta;

b) kalki: coup d'État - zamach stanu; Corps Législatif - Ciało Ustawodawcze; Charte constitutionnelle - Karta konstytucyjna; Empire Français - Imperium Francuskie;

c) thumaczenia dosłowne poprawne gramatycznie, frazeologicznie oraz leksykalnie, nazywane również w literaturze przedmiotu tłumaczeniami literalnymi w odróżnieniu od thumaczeń dosłownych niepoprawnych gramatycznie, leksykalnie i frazeologicznie;

d) transpozycje czyli: jak wróci do domu - when he comes back, when he returns

e) modulacje np.: nie jest latwo... - jest trudno...

f) ekwiwalencję nazywaną $\mathrm{w}$ literaturze przedmiotu ekwialencją dynamiczną lub funkcjonalną ${ }^{2}$ czyli np. przekład angielskiego ouch na polskie aua, czy też przekład idiomów np.: too many cooks spoil the broth na polskie gdzie kucharek sześć tam nie ma cojeść;

g) adaptację - stosowaną np. przy przekładzie tytułów filmów czy książek tam gdzie brak ekwiwalentów i gdzie tłumacz musi wymyślić coś zrozumiałego dla odbiorcy.

Metody zapewnania ekwiwalencji opracowane przez Darbelnet i Vinaya zostały początkowo uznane za przełomowe. W późniejszym okresie jednak zauważono, iż istnieją niekiedy problemy z rozróżnieniem poszczególnych typów ekwiwalentów - może się mianowicie zdażyć, iż np. zapożyczenie jest jednocześnie ekwiwalenetm dynamicznym.

Kierzkowska (2002: 118-123) mówi natomiast o

$>$ ekwiwalentach naturalnych (funkcjonalnych) dalekich;

$>$ ekwiwalentach naturalnych (funkcjonalnych) bliskich;

$>$ ekwiwalentach seminaturalnych;

$>$ kalkach leksykalnych wyrazowych;

$>$ zapożyczeniach prostych;

$>$ zapożyczeniach naturalizowanych;

$>$ ekwiwalentach opisowych; oraz

$>$ ekwiwalentach frazeologicznych.

Do najczęściej stosowanych metod zapewniania ekwiwalentów należą zapożyczenia. Haugen (1950:212) stwierdza, że ,borrowing is then the attempted reproduction in one language of patterns previously found in another". Do zapożyczeń zalicza się zapożyczenia bezpośrednie tzn. egzotyki, oraz zapożyczenie z dostosowaniem pisowni do zasad rządzących językiem docelowym, kalki i hybrydy. Natomiast Faber, Hjort-Pedersen i Klinge (1996/97:21) mówią o dwóch typach przekładu, mianowicie:

$>$,a target language orientation. This means that the translator tries to make her text look as much as possible like an original target language document. Consequently, she will orient her translation towards the target language community by imitating the way in which parallel documents are designed in the target language community and by borrowing linguistic material from such parallel texts in her translation purposes. In this case, then, there is little resemblance with the source text".

$>$, a source language orientation. This means that the translator does not make her translation look like an original target language document, but instead orientates her translation towards the source language community by imitating the way in which the source language document is designed and by seeking to transfer semantically or nearliterally the linguistic choices initially made by the source text producer. This means that there is a much higher degree of resemblance with the source text". I analogicznie wyróżniają ekwiwalenty zorientowane na język źródłowy i docelowy.

\footnotetext{
${ }^{2}$ terminy ekwiwalent funkcjonalny i ekwiwalent formalny zostały wprowadzone do językoznawstwa przez Nidę (1964).
} 
Dla potrzeb tego artykułu autorki wyróżniły poniżej opisane metody zapewnaniania ekwiwalentów stosowane w tekstch medycznych, biotechnologicznych i biologicznych.

1. Egzotyk to rodzaj zapożyczenia zachowujący pisownię terminu języka docelowego. Termin egzotyk został ukuty przez Fisiaka (1961:108) i zdefiniowany jako ,concepts strictly connected with the source-language culture and unknown in a target-language legal reality the spelling of which is preserved in the target-language" (Matulewska 2007), np.:

\begin{tabular}{|c|c|}
\hline crossing-over & crossing-over \\
\hline splicing & splicing \\
\hline telomer & telomer \\
\hline mutant & mutant \\
\hline
\end{tabular}

2. Zapożyczenie z dostosowaniem pisowni do zasad rządzących językiem docelowym „show morphemic importation without substitution. Any morphemic importation can be further classified according to the degree of its phonemic substitution: none, partial, or complete" (Haugen 1950:62), np.:

\begin{tabular}{|c|c|}
\hline cytosol & cytozol, cytosol \\
\hline transposon & transpozon \\
\hline attenuation & atenuacja \\
\hline biotechnology & biotechnologia \\
\hline deletion & delecja \\
\hline lyophilization & liofilizacja \\
\hline ultrafiltration & ultrafiltracja \\
\hline activator & aktywator \\
\hline adjuvant & adjuwant \\
\hline antibiotic & antybiotyk \\
\hline anticodon & antykodon \\
\hline
\end{tabular}

3. Kalki natomiast to zapożyczenia, które ,show morphemic substitution without importation. In this group we may include what are usually called loan translation and semantic loan; the term shift is suggested because they appear in the borrowing language only as functional shifts of native morphemes" (Haugen 1950: 62), np.:

\begin{tabular}{|c|c|}
\hline amino sugar & aminocukier \\
\hline anaerobic respiration & $\begin{array}{l}\text { oddychanie beztlenowe, oddychanie } \\
\text { anaerobowe }\end{array}$ \\
\hline angiotensin-converting enzyme (ACE) & enzym przeksztłcający angiotensynę \\
\hline Antibody & przeciwciało \\
\hline antigen presenting cells, APC & komórki prezentujące antygen \\
\hline Antioxidant & antyutleniacz, przeciwutleniacz \\
\hline antitermination protein & białko antyterminacyjne \\
\hline base excision repair, BER & naprawa przez wycinanie zasad \\
\hline beta-turn & skręt beta \\
\hline blunt ends & tępe końce \\
\hline botulinum toxin & $\begin{array}{c}\text { toksyna botulinowa, toksyna jadu } \\
\text { kiełbasianego }\end{array}$ \\
\hline catabolic repression & represja kataboliczna \\
\hline cell culture & kultura komórkowa, hodowla komórkowa \\
\hline competent bacteria & bakterie kompetentne \\
\hline contact allergy & alergia kontaktowa \\
\hline dispersive replication model & dyspersyjny model replikacji \\
\hline
\end{tabular}


Patrycja Kłos, Aleksandra Matulewska, Paulina Nowak-Korcz: Problemy przekładu specjalistycznego na przykładzie tekstów z dziedziny prawa, biologii, biotechnologii i medycyny.

\begin{tabular}{|c|c|}
\hline disulphide bridge & mostek dwusiarczkowy, mostek disiarczkowy \\
\hline electron transport chain & $\begin{array}{c}\text { lańcuch transportu elektronów, } \\
\text { łańcuch oddechowy }\end{array}$ \\
\hline
\end{tabular}

4. Hybrydy „show morphemic substitution as well as importation. All substitution involves a certain degree of analysis by the speaker of the model that he is imitating; only such «hybrids» that involve a discoverable foreign model are included here" (Haugen 1950:62), np.:

\begin{tabular}{|c|c|}
\hline freeze fracture (method) & $\begin{array}{c}\text { metoda łamania mrożonego materiału, } \\
\text { metoda freeze fracture }\end{array}$ \\
\hline genetic marker & marker genetyczny \\
\hline
\end{tabular}

5. Ekwiwalenty funkcjonalne czyli zastosowanie najbliższego ekwiwalentu znanego w rzeczywistości docelowego języka specjalistycznego, np.:

\begin{tabular}{|l|c|}
\hline designer proteins & białka projektowane \\
\hline rocking platform & kołyska laboratoryjna \\
\hline
\end{tabular}

6. Neologizmy to ,newly coined words, or phrases or familiar words used in a new sense. They are useful as they help create equivalents, the meaning of which is intuitively understandable despite the fact that they do not exist in a target-language legal reality" (Matulewska 2007). Czyli są to zupełnie nowe terminy nieznane w kulturze języka docelowego ukute na potrzeby komunikacji, np.:

\begin{tabular}{|c|c|}
\hline vortex shaker & worteks, wortex \\
\hline
\end{tabular}

7. Ekwiwalent opisowy w postaci definicji wśród których wyróznia się definicje wyczerpujące wyliczające pełen katalog cech składających się na znaczenie danego terminu (equity $\rightarrow$ system prawny oparty na zasadzie stuszności obecnie stosowany $w$ Wielkiej Brytanii i Stanach Zjednoczonych), definicje zawężające przedstawiające skrócony katalog cech składających się na znaczenie danego terminu (judge-commissioner is a person who manages and supervises the course of the Polish bankruptcy proceedings) oraz definicje poszerzające nadające terminowi szersze znaczenie czyli poszerzajace katalog cech składających się na znaczenie danego terminu o nowe cechy (np ryby wód stodkowodnych to $w$ polskim prawie ryby wód słodkowodnych i raki) np.:

\begin{tabular}{|c|c|}
\hline blotter & $\begin{array}{c}\text { aparat do transferu DNA/RNA/białek na } \\
\text { membrany }\end{array}$ \\
\hline
\end{tabular}

8. Ekwiwalent opisowy nawiązujący do podobnego pojęcia znanego w kulturze języka docelowego np.: kodeks postępowania karnego - Code d'instruction criminelle Polonais.

9. Termin hiperonimiczny czyli zastosowanie terminu szerszego znaczeniowo na oddanie terminu węższego znaczeniowo w języku źródłowym nazywany także ekwiwalentem poszerzającym, np.

\begin{tabular}{|c|c|}
\hline fingers & palce \\
\hline substitution & mutacja punktowa \\
\hline insertion & mutacja punktowa \\
\hline
\end{tabular}

10. Termin hiponimiczny na oddanie znaczenia hiperonimu użytego $\mathrm{w}$ tekście źródłowym nazywany także ekwiwalentem ograniczającym, np.: 


\begin{tabular}{|c|c|}
\hline palce & finders \\
\hline palce & toes \\
\hline lichen & porost \\
\hline affinity & powinowactwo przeciwciała \\
\hline
\end{tabular}

11. W przypadku nieprzystawalności pola znaczeniowego terminów niekiedy jest konieczne zastosowanie dwóch lub więcej terminow na oznaczenie jednego o zakresie znaczeniowym hiperonimicznym w stosunku do istniejących terminów języka docelowego np.: spótkasociété et compagnie; palce - fingers and toes.

12. Ekwiwalent zorientowany na język źródłowy modyfikujący termin znany w kulturze języka docelowego np.: Gouvernement de la République Française - Rzad Tymczasowy Republiki Francuskiej,

\begin{tabular}{l|r} 
linkage & sprzężenie genetyczne \\
\hline
\end{tabular}

13. Ekwiwalent ponadkulturowy, który w naukach biologicznych, medycynie do łaciny, a w prawie najczęściej nawiązuje do prawa rzymskiego, np.:

\begin{tabular}{|c|c|}
\hline eukaryotic organisms & organizmy eukariotyczne \\
\hline prokaryotic organisms & organizmy prokariotyczne \\
\hline oncogenesis & ontogeneza \\
\hline
\end{tabular}

Nie jest to wyczerpująca lista strategii thumaczeniowych, ale $\mathrm{z}$ całą pewnością $\mathrm{w}$ większości sytuacji pozwoli na stworzenie odpowiedniego ekwiwalentu.

Należałoby się również przyjrzeć zjawisku „niezgodności leksykalnej”, omawianej przez Dzierżanowską (1990: 90). Efektem niezgodności leksykalnej są błędy leksykalne, wśród których Dzierżanowska wyróżnia: błędy w zakresie niezgodności leksykalnej wyrazów; błędy wynikające z różnic terminologicznych; błędy wynikające $\mathrm{z}$ niezgodności leksykalnej grup wyrazowych, powstające na skutek niepoprawnego tworzenia łączliwych i luźnych związków frazeologcznych pod wpływem interferencji thumaczonego tekstu. W procesie przekładu, najważniejszą rolę odgrywają związki stałe, czyli wyrażenia idiomatyczne, jak również kolokacje (czyli związki łączliwe). Z kolei idiomy są płaszczyzną frazeologii „najbardziej odporną na wpływy obce i najrzadziej przenoszoną z jednego języka do drugiego" (Kurkowska, Skorupka 2001: 166). Przekład wyrażeń idiomatycznych należy zatem traktować ze szczególną ostrożonością jak pisze Dzierżanowska (1990: 31). Podobnie sytuacja przedstawia się z kolokacjami, których tworzenie nie jest dowolne. Każdy język posiada własne, odrębne kolokacje, które cechuje nieprzekładalność, a najmniejsze naruszenie ich struktury prowadzi do zmiany znaczenia. Kolokacje w języku ojczystym powstają instynktownie, natomiast tych w języku obcym należy się wyuczyć. W przeciwnym razie, niewłaściwe tworzenie związków frazeologicznych prowadzi do licznych błędów w przekładzie.

$\mathrm{W}$ analizowanych tekstach z dziedziny biologii, biotechnologii i medycyny problemy związane $\mathrm{z}$ nieznajomością dziedziny oraz terminologii języka specjalistycznego, doprowadziły do powstania błędów tłumaczeniowych opisanych poniżej:

Przykład 1.

- W tekście angielskim termin: soybean przetłumaczony został jako: nasiona soi, a powinien zostać przetłumaczony jako: soja. Nie doszło w tym przypadku do zmiany znaczenia, ale jest to błąd terminologiczny.

Przykład 2

- Angielski termin: tree nuts, przetłumaczono na język polski jako: owoce drzew orzechowych. Właściwe thumaczenie tego terminu to: orzechy. Nie doszło tutaj do zmiany znaczenia. 
Przykład 3

- Angielski termin: spelt, został błędnie przetłumaczony jako: pszenica oplewiona, zamiast: orkisz. Nie doszło do zmiany znaczenia, ale sformułowanie jest trudne do zrozumienia.

Przykład 4

- Termin z wersji angielskiej: respiratory organs, przetłumaczono na język polski jako: układ oddechowy, zamiast: narzady oddechowe. Doszło do zmiany znaczenia.

Przykład 5.

- Angielski termin: control of bacteria, przetłumaczony na język polski jako: zwalczanie bakterii, powinien zostać przetłumaczony jako: ogranicznie (rozwoju) bakterii. Jest to błąd terminologiczny, prowadzący do zmiany znaczenia.

Przykład 6.

- Tłumaczenie angielskiego terminu: decontamination, jako: unieszkodliwianie, jest błędem terminologicznym, prowadzącym do zmiany znaczenia. Termin ten powinien zostać przetłumaczony na język polski jako: odkażanie.

Przykład 7.

- Termin z wersji angielskiej: target organs, przethumaczono jako: organów zwalczanych, zamiast: organów atakowanych. Jest to błąd terminologiczny, prowadzący do zmiany znaczenia.

Przykład 8.

- Fragment z wersji angielskiej: ...interpretations from animal data..., przetłumaczono na język polski jako: ...danych uzyskanych dzięki zwierzętom..., zamiast: ...danych uzyskanych dzięki badaniom na zwierzętach.... Także w tym przypadku, mamy do czynienia ze zmianą Przykład 9. znaczenia i błędem terminologicznym.

- Fragment $\mathrm{z}$ wersji angielskiej: Methods for the analysis of the micro-organism..., przetłumaczono na język polski jako: metody analityczne drobnoustroju...., co doprowadziło do zmiany znaczenia. Właściwe tłumaczenie tego fragmentu brzmi następująco: metody analizy drobnoustroju....

Przykład 10.

- Angielski fragment: The way of administration of the test micro-organism depends on the main exposure routes to humans, przetłumaczono jako: Sposób przeprowadzania badań drobnoustrojów zależy od głównych dróg narażenia ludzi, zamiast: Sposób podania mikroorganizmu testowego zależy od głównych dróg narażenia ludzi. To kojeny błąd terminologiczny prowadzący do zmiany znaczenia.

Przykład 11

- Angielski fragment: ...blood analyses throughout the studies..., brzmiący w polskiej wersji ...analizy krwi wykonywane poprzez badania..., powinien zostać przetłumaczony jako: ...analizy krwi wykonywane przez cały czas badań... Również w tym przypadku mamy do czynienia z błędem terminologicznym, prowadzącym do zmiany znaczenia.

Przykład 12.

- Angielski fragment: ...used for biological control..., przethumaczony jako: ...wykorzystywane do zwalczania biologicznego..., powinien zostać przetłumaczony jako: ...wykorzystywane do kontroli biologicznej... Jest to błąd terminologiczny, prowadzący do zmiany znaczenia.

Przykład 13.

- Błędne thumaczenie fragmentu z wersji angielskiej: ...gross pathological findings..., jako: ...ogólne zmiany patologiczne..., doprowadziło do zmiany znaczenia thumaczonego fragmentu. Fragment ten powinien zostać przetłumaczony jako: ...poważne zmiany patologiczne...Błąd polega w tym przypadku na zastosowaniu niewłaściwego ekwiwalentu dla terminu gross.

Przykład 14.

- Fragment $\mathrm{z}$ wersji angielskiej: ...macroscopic and microscopic pathology is to be performed..., przetłumaczono błędnie na język polski jako: ...należy przeprowadzić 
makroskopowe i mikroskopowe badania laboratoryjne..., zamiast thumaczenia: ...należy przeprowadzić makroskopowe $i$ mikroskopowe badania patologiczne... Jest to błąd terminologiczny prowadzący do zmiany znaczenia.

Przykład 15.

- Termin z wersji angielskiej: latent infection, przetłumaczono jako: zakażenie ukryte, zamiast: zakażenie utajone. Nie doszło tutaj do zmiany znaczenia. Tłumacz dokonał błędnego wyboru przymiotnika, co w konsekwencji doprowadziło również do zakłócenia związku frazeologicznego (kolokacji).

Przykład 16.

- Termin angielski: culture collection, przetłumaczono jako: kolekcja hodowli, zamiast: kolekcja kultur. Nie dochodzi w tym przypadku do zmiany znaczenia, które można wydedukować, jednak jest to błąd polegający na zakłóceniu związku frazeologicznego.

Przykład 17.

- Angielski fragment: statistically significant/non significant, został przetłumaczony jako: znaczny/nieznaczny (statystycznie), zamiast: istotny/nieistotny (statystycznie). Jest to również błąd frazeologiczny, który nie prowadzi jednak do zmiany znaczenia thumaczonego zwrotu.

Przykład 18.

- W tekście angielskim występuje termin: culture medium, w polskim jest: pożywka hodowli, zamiast: pożywka hodowlana. Nastapiła zmiana znaczenia, chociaż właściwe znaczenie można wydedukować, gdyż termin pożywka hodowli nie występuje w rzeczywistości.

Przykład 19.

- W tekście angielskim występuje termin: avian strains, w polskim: szczep avian, zamiast: szczepy ptasie. Stworzony neologizm prowadzi do zmiany znaczenia. Thumacz powołał do istnienia byt nieistniejący, ponadto mamy to do czynienia $z$ błędem gramatycznym, a mianowicie zastosowaniem liczby pojedynczej zamiast mnogiej.

Przykład 20.

- W tekście angielskim jest: respiratory syncytial virus, a w polskim: wirus oddechowego scyntium, w polskim powinno być: wirus syncytium nabłonka oddechowego (RSV). Zmiana znaczenia, neologizm ukuty przez tłumacza prowadzi do niezrozumienia tekstu.

Przykład 21.

- fragment z wersji angielskiej został błędnie przetłumaczony na język polski w następujący sposób: Komisja, po konsultacji z Europejskim Urzędem ds. Bezpieczeństwa Żywności, przyjmuje wykaz tych składników lub substancji, które zostaja $w$ konsekwencji usunięte $z$ załacznika IIIa, do czasu otrzymania ostatecznych wyników notyfikowanych badań lub najpóźniej do dnia 25 listopada 2007 r. Powyższy fragment powinien zostać przetłumaczony natomiast jako: Komisja, po konsultacji z Europejskim Urzędem ds. Bezpieczeństwa Żywności, przyjmuje wykaz tych składników lub substancji, które zostaja w konsekwencji usunięte z załqcznika IIIa, do czasu otrzymania ostatecznych wyników zgłoszonych badań lub najpóźniej do dnia 25 listopada 2007 r. Błąd ten jest wynikiem błędnego przetłumaczenia angielskiego czasownika to notify - zawiadamiać. Czasownik ten został przetłumaczony dosłownie jako: notyfikować, co jest kalką z języka angielskiego. W efekcie mamy do czynienia z utworzeniem neologizmu leksykalnego. Po polsku mówi się o zgłoszonych badaniach a nie o notyfikowanych badaniach.

\section{Problemy tłumaczeniowe wynikające z nieznajomości języka ojczystego i obcego}

Zawód tłumacza wymaga nie tylko solidnego i specjalistycznego wykształcenia, odpowiednich predyspozycji, ale również ustawicznego dokształcania się. Dobry thumacz powinien posiadać przede wszystkim właściwe kompetencje (w zakresie znajomości języka obcego jak i ojczystego, dziedziny do której należy tłumaczony tekst, strategii tłumaczeniowych, czy też zasad przekładu). Doskonała znajomość języka ojczystego i obcego w zakresie ortografii, interpunkcji, stylistyki, fleksji, a szczególnie składni obu języków to wymagania, które współcześnie nie zawsze są spełniane przez tłumaczy, co uwidacznia się w postaci licznych błędów gramatycznych. Według 
Hejwowskiego (2004: 154) „Przez dobrą znajomość języka rozumiemy bogate słownictwo, duży zasób syntagm i ram czasownikowych, a także opanowanie wielu innych mechanizmów gramatycznych, takich jak zastosowanie czasów, przedimków, czasowników modalnych i zdań przydawkowych $\mathrm{w}$ języku angielskim (żeby wspomnieć tylko o problemach gramatycznych najbardziej dokuczliwych z polskiego punktu widzenia) oraz na przykład znajomość końcówek (deklinacji i koniugacji) i ortografii języka polskiego". Ponadto, ten sam autor analizując źródła błędów w tłumaczeniu na język ojczysty, wyróżnia obok błędów interpretacji, błędów thumaczenia powierzchniowego, oraz błędów metatranslacyjnych - błędy realizacji. W obrębie błędów realizacji Hejwowski (2001: 158) wyróżnia dwie kategorie błędów: błędy językowe, spowodowane niedostateczną znajomością języka ojczystego, ale głównie wynikających z nieuświadomienia sobie własnej niedoskonałości $\mathrm{w}$ tej dziedzinie oraz błędy, będące błędnymi decyzjami wynikającymi ze złej oceny wiedzy odbiorcy tekstu niezrozumiałego lub przeciwnie - zbyt oczywistego, zawierającego ponadto informacje zbędne. Natomiast, Nowak (za Dzierżanowską 1990: 82) dokonując klasyfikacji błędów w tłumaczeniu wyróżnia następujące typy błędów gramatycznych: (i) w formach morfologicznych; (ii) w elementach struktury grupy wyrazowej; (iii) w elementach struktury zdania. Nowak (2006: 181-182) wyróżnia wśród błędów gramatycznych błędy fleksyjne i składniowe. W analizowanych dyrektywach, problemy wynikające $\mathrm{z}$ nieznajomości reguł języka ojczystego i obcego doprowadziły do powstania głównie błędów składniowych, a szczególnie konstrukcji niepoprawnch pod względem szyku, wynikających z niezrozumienia składni języka obcego, zakłóceń związku zgody i rządu, oraz błędów w używaniu przyimków.

Poniżej przedstawiono przykładowe błędy gramatyczne, wynikające z niezrozumienia składni języka obcego przez thumacza.

Przykład 1.

- Fragment $\mathrm{z}$ wersji angielskiej: ...the stability of the genes coding for antibiotic resistance..., przetłumaczono błędnie na język polski jako: ...stabilności kodowania genów na odporność przeciwko antybiotykom..., zamiast: ...stabilność genów kodujacych oporność na antybiotyki... Doszło w tym przypadku do zmiany znaczenia thumaczonego fragmentu. Logicznym jest fakt, że genów nie da się kodować, ponieważ to geny kodują. Błąd wynika w tym przypadku z niezrozumienia składni angielskiej przez thumacza.

Przykład 2.

- Termin z wersji angielskiej: production method/process, został przetłumaczony błędnie jako: metody produkcji/procesu, zamiast thumaczenia: metody produkcji/proces produkcji. Błąd jest wynikiem niezrozumienia składni angielskiej przez tłumacza i prowadzi do zmiany znaczenia.

Najczęściej występujące błędy gramatyczne dotyczą zakłócenia związków zgody i rządu. Przykład 1.

- Pracodawcy niezwłocznie informuja pracowników lub wszelkich przedstawicieli pracowników o każdej awarii lub wypadku, który mógt spowodować uwolnienie sie czynnika biologicznego i który mógt być przyczynq poważnego zakażenia ludzi i/lub choroby. W tym fragmencie mamy do czynienia z błędem gramatycznym polegającym na zakłóceniu związku zgody. Powyższy fragment powinien zostać przetłumaczony w następujący sposób: Pracodawcy niezwłocznie informuja pracowników lub wszelkich przedstawicieli pracowników o każdej awarii lub wypadku, które mogły spowodować uwolnienie się czynnika biologicznego i które mogły być przyczynq poważnego zakażenia ludzi i/lub choroby. Znaczenie nie zostało zmienione.

Przykład 2.

- Dodatkowo, w razie zaistnienia poważnej awarii lub wypadku, pracodawcy informuja tak szybko jak to jest możliwe pracowników lub przedstawicieli pracowników $w$ przedsiębiorstwie lub zaktadzie o jego przyczynach oraz o podjętych i proponowanych środkach, majacych na celu opanowanie sytuacji. W tym przykładzie również doszło do zakłócenia związku zgody. Poprawna wersja tego fragment powinna brzmieć w 
następujący sposób: Dodatkowo, w razie zaistnienia poważnej awarii lub wypadku, pracodawcy informuja tak szybko jak to jest możliwe pracowników lub przedstawicieli pracowników $w$ przedsiębiorstwie lub zakładzie o ich przyczynach oraz o podjętych $i$ Przykład 3. proponowanych środkach, majacych na celu opanowanie sytuacji. Brak zmiany znaczenia.

- We fragmencie: Każdy pracownik posiada dostęp do informacji na temat wykazu, określonego $w$ art. 11, który dotyczy go osobiście również naruszono związek zgody. Właściwe thumaczenie to: Każdy pracownik posiada dostęp do informacji na temat wykazu, określonego w art. 11, które dotyczq go osobiście. Doszło w tym przypadku do zmiany znaczenia.

Przykład 4.

- Kolejny przykład naruszenia związku zgody można znaleźć w następującym fragmencie: Jeżeli zostaje stwierdzone, że pracownik cierpi z powodu zakażenia i/lub choroby, która może być skutkiem narażenia, lekarz lub organ odpowiedzialny za kontrole zdrowotna pracowników proponuje przeprowadzenie takiej kontroli pozostałym pracownikom, którzy byli podobnie narażeni. Prawidłowe tłumaczenie powyższego fragment powinno wyglądać w następujący sposób: Jeżeli zostaje stwierdzone, że pracownik cierpi z powodu zakażenia i/lub choroby, które moga być skutkiem narażenia, lekarz lub organ odpowiedzialny za kontrole zdrowotna pracowników proponuje przeprowadzenie takiej kontroli pozostałym pracownikom, którzy byli podobnie narażeni. Znaczenie nie zostało zmienione.

Poniżej zaprezentowano przykład błędu w konstrukcji przyimkowej.

- W celu osiagnięcia wysokiego poziomu ochrony zdrowia konsumentów i zagwarantowania im prawa do informacji należy zapewnić, aby konsumenci byli odpowiednio informowani $w$ odniesieniu do środków spożywczych, między innymi poprzez umieszczanie na etykietach informacji o wszystkich składnikach. W powyższym fragmencie doszło do powstania błędu gramatycznego polegającego na zastosowaniu nieodpowiedniego przyimka. Poprawna wersja powyższego fragmentu to: $W$ celu osiagnięcia wysokiego poziomu ochrony zdrowia konsumentów $i$ zagwarantowania im prawa do informacji należy zapewnić, aby konsumenci byli odpowiednio informowani o środkach spożywczych, między innymi poprzez umieszczanie na etykietach informacji o wszystkich sktadnikach.

\section{Nieznajomość języka specjalistycznego}

Wiele problemów thumaczeniowych, wynika z braku znajomości języka specjalistycznego u thumacza. Język specjalistyczny to „odmiana języka narodowego, charakteryzująca się specjalistyczną terminologią i odpowiednimi środkami ekspresji, typowymi dla tekstów danej dziedziny. Powyższa definicja odnosi się zarówno do odmian języka naukowego (np. biologii, fizyki), technicznego (np. elektrotechniki, przemysłu tworzyw sztucznych), zawodowego (np. architektury, prawa, ekonomii), rzemieślniczego (np. rzeźnictwa, stolarstwa), jak i tych, które odnoszą się do życia społecznego (np. polityki, sportu, rozrywki, związków zawodowych)" (Delisle 2004: 50). Ponadto, szczególnie istotny jest fakt, że „pojęcie języka specjalistycznego, nie ogranicza się do terminologii. Język specjalistyczny charakteryzuje się również pojęciami funkcjonalnymi (opisującymi czynności i procesy) oraz specyficzną składnią. Na przykład, w niektórych odmianach języka specjalistycznego odnotowujemy dużą liczbę konstrukcji pasywnych i form bezosobowych. (...) język specjalistyczny określany jest również jako język tekstów specjalistycznych, z tym, że termin język specjalistyczny jest pojęciem szerszym, gdyż jest to również język komunikacji ustnej, między fachowcami” (Delisle 2004: 50).

$\mathrm{W}$ rozumieniu niniejszego artykułu język medycyny, biologii i biotechnologii jest językiem specjalistycznym (language for special purposes) - odmianą zawodową języka fachowego (language for occupational purposes). Należy tutaj odróżnić odmianę zawodową języka fachowego (language for occupational purposes) od odmiany języka specjalistycznego akademickiego (language for academic purposes) - tą drugą posługują się wykładowcy nauczający przedmiotów 
związanych z wyżej wymienionymi dziedzinami oraz studenci, którzy uczą się medycyny, biologii i biotechnologii.

Efektem nieznajomości języka specjalistycznego u tłumaczy są najczęściej błędy rejestru oraz błędy stylistyczne (przykładowo: używanie języka potocznego zamiast specjalistycznego, używanie elementów potocznych o charakterze oficjalnym, stylizacja językowa niemająca uzasadnienia $\mathrm{w}$ treści i charakterze stylowym wypowiedzi, niespójne konstrukcje składniowe, niespójność pod względem treści, tautologie, nieudane porównania czy też metafory). Należy w tym miejscu zaznaczyć, że każdy język, posiada wiele odmian i stylów, a „zasadą, od której nie wolno robić odstępstw, jest jednolitość stylu. Tekst pisany mieszaniną stylów czyta się źle" (Dzierżanowska 1990: 100). Również (Dickel 2003: 145) podkreśla wagę jednoznaczności w tłumaczeniu specjalistycznym następującymi słowami: „Z koncentracji nad treścią i przedmiotem thumaczenia fachowego wypływa redukcja indywidualnych wariantów stylu w tekstach fachowych. Zamiast metaforycznych czy ironicznych wyrażeń, występuje dokładność, jednoznaczność i ekonomiczność wyrażeń". Natomiast Karczewska (2002, za Bartmiński 1993: 20) pisze następująco: „O tożsamości stylu decyduje zespół «zadanych» podstawowych wartości (np. zasada ścisłości i jednoznaczności w stylu naukowym, obrazowości w stylu artystycznym, jasności w stylu urzędowym itp.). Style obejmują określone założenia dotyczące ontologii świata, typu racjonalności, postawy podmiotu, intencjonalności. Wartości stylu otrzymują na poziomie tekstu odpowiadające im eksponenty formalne". W thumaczeniu analizowanych dyrektyw unijnych oraz tekstach podręczników, nieznajomość języka specjalistycznego u tłumacza, doprowadziła do powstania następujących błędów rejestru, oraz tautologii.

Przykład 1.

- Angielski termin: pistachio nut, przetłumaczono na język polski jako: fistaszek, zamiast: orzech pistacjowy. Nastapiła zmiana znaczenia. Po pierwsze fistaszek jest nazwa handlowa oraz nazwą spotykaną w języku potocznym, po drugie jest to nazwa potoczna orzecha ziemnego a nie pistacjowego. Jest to zarazem błąd stylistyczny, polegający na zastosowaniu języka potocznego zamiast specjalistycznego oraz błąd terminologiczny. Błąd rejestru.

Przykład 2.

- Termin z wersji angielskiej: starting cultures, przetłumaczono jako: metody kultury wyjściowe, zamiast: kultury starterowe. Jest to błąd rejestru, nie dochodzi jednak w tym przypadku do zmiany znaczenia.

Przykład 3.

- Fragment z wersji angielskiej: ...(including the host specificity)..., przethumaczono na język polski jako: ...(z uwględnieniem specyfiki żywiciela)..., zamiast: ...(z uwzględnieniem specyficzności żywicielskiej)...Nie dochodzi w tym przypadku do zmiany znaczenia, niemniej jednak jest to błąd rejestru.

Przykład 4.

- Przetłumaczenie angielskigo terminu: shelf-life, jako: trwałość, doprowadziło do powstania błędu rejestru. Poprawne tłumaczenie powinno brzmieć: okres składowania/data przydatności. Brak zmiany znaczenia.

Przykład 5.

- Angielski fragment: in accident situations, przethumaczono na język polski jako: $w$ przypadkach incydentalnych..., zamiast: $w$ sytuacjach przypadkowych. W tym przypadku mamy do czynienia z niezamierzoną tautologia.

\section{Inne problemy thumaczeniowe}

W trakcie thumaczenia tekstów specjalistycznych pojawiają się również inne problemy thumaczeniowe. Wynikają one po pierwsze - ze zbyt bliskich kontaktów między językami (gdy formy języka źródłowego wpływają na formy przyjęte w języku docelowym); po drugie $-\mathrm{z}$ niezrozumienia przez thumacza tekstu oryginału; po trzecie - z nieprzystawania tekstu przekładu do tekstu oryginału, gdzie dodano lub opuszczono pewne istotne informacje, bądź też zbyt oddalono się w interpretacji od intencji oryginału (Pisarska, Tomaszkiewicz 1996: 144). Błędy wynikające w 
niezrozumienia tekstu, gdzie tłumacz mylnie zinterpretował intencje autora, moga prowadzić $\mathrm{w}$ efekcie do powstania: (i) sensu fałszywego (czyli innego niż w oryginale); (ii) sensu przeciwnego (który zmienia zupełnie intencje autora); (iii) nonsensu, czyli wyrażenia kompletnie absurdalnego. Ponadto, wiele błędów thumaczeniowych jest wynikiem niezgodności istotnych informacji w stosunku do oryginału. Zbyt mała ilość informacji w tłumaczeniu uwidacznia się głównie w opuszczeniach, w tzw. lukach w przekładzie, które Dzierżanowska (1990: 101) określa mianem „niadekwatności semantycznej”. Natomiast Hejwowski (2004: 144) thumaczy fakt opuszczania informacji w przekładzie w następujący sposób: „Pokusa opuszczenia fragmentu tekstu pojawia się wtedy, gdy thumacz nie rozumie danego sformułowania lub nie potrafi znaleźć zadowalającego ekwiwalentu w języku docelowym. Tego typu trudności świadczą na ogół o lukach w kompetencji thumaczeniowej, a nie o tym, że opuszczenie jest rzeczywiście uzasadnione". Również dodanie zbyt dużej ilości informacji w tekście przekładu jest błędem i prowadzi często do zmiany znaczenia. O nieuzasadnionych dodaniach informacji pisze Hejwowski (2004: 144), nazywając je „pustymi ozdobnikami” lub „wypełniaczami”. Również Hejwowski dokonuje ciekawej klasyfikacji błędów tłumaczeniowych, nazywając je błędami metatranslacyjnymi, które są „efektem nieświadomości tłumacza co do pewnych ogólnie przyjętych zasad tłumaczenia albo nawet niezrozumienia podstawowego celu przekładu, jakim jest umożliwienie komunikacji międzykulturowej" (Hejwowski 2004: 168). Do tego typu błędów zaliczył on: (i) niewłaściwy dobór techniki tłumaczeniowej (nietłumaczenie elementów, które powinny zostać przełożone; stosowanie thumaczenia syntagmatycznego tam, gdzie powinny zostać użyte techniki thumaczenia funkcjonalnego; (ii) nieuzasadnione opuszczenia; (iii) nieuzasadnione dodatki; (iv) pozostawienie dwóch wersji danego fragmentu przekładu; (v) poprawianie oryginału w tych miejscach, w których nie wymaga on poprawek; (vi) niepoprawianie oryginalnego tekstu informacyjnego, w miejscu, gdzie zawiera on błędy; (vii) umieszczanie w tekście przekładu za dużo lub za mało informacji. W analizowanych tekstach $\mathrm{z}$ dziedziny biologii, biotechnologii i medycyny znaleziono przykłady opuszczeń istotnych informacji, nonsensów, jak również przykłady dotyczące zmiany znaczenia tłumaczonych fragmentów. Poniżej niektóre z nich.

Przykład 1.

- Fragment z tekstu angielskiego brzmi: its susceptible stages, został on przetłumaczony na polski jako: jego etapy, natomiast powinien zostać przetłumaczony jako: jego newralgiczne etapy. Tłumacz opuścił zatem istotną informację, co w efekcie doprowadziło do zmiany znaczenia.

Przykład 2.

- W tekście angielskim znajdujemy fragment: Interference with the use of antibiotics in human or veterinary medicine must be avoided.... Fragment ten został przetłumaczony jako: ...nie wolno dopuścić do zaktóceń zwiqzanych ze stosowaniem antybiotyków wobec ludzi lub leków weterynaryjnych..., powinien natomiast zostać przetłumaczony jako: ...nie wolno dopuścić do zaktóceń zwiqzanych ze stosowaniem antybiotyków $w$ medycynie czlowieka lub medycynie weterynaryjnej/weterynarii. Mamy tutaj do czynienia $\mathrm{z}$ Przykład 3. nonsensem, który prowadzi do zmiany znaczenia thumaczonego fragmentu.

- Fragment $\mathrm{z}$ tekstu angielskiego: ...the risk of insertional mutagenesis in mammal cells..., został przetłumaczony jako: ...ryzyko mutagenezy wprowadzonej do komórek ssaków..., a powinnien zostać przetłumaczony jako: ...ryzyko mutagenezy insercyjnej $w$ komórkach ssaków... W tym przypadku mamy niewątpliwie do czynienia ze zmianą znaczenia tłumaczonego fragment. Powstał w tym przypadku nonsens, który jest wynikiem niezrozumienia składni języka angielskiego przez tłumacza.

Przykład 4.

- W tekście angielskim znajdujemy fragment: acute percutaneous toxicity, a polskie thumaczenie tego fragment brzmi: ostra toksyczność dootrzewnowa, a powinno brzmieć: ostra przezskórna toksoza/ostra przezskórna toksyczność. W tym przypadku również mamy do czynienia $\mathrm{z}$ nonsensem, który prowadzi do zmiany znaczenia tłumaczonego fragmentu. 
Przykład 5.

- Termin z tekstu angielskiego: freshwater invertebrates, został przetłumaczony na polski jako: kręgowce słodkowodne, a powinien zostać przetłumaczony jako: bezkręgowce stodkowodne. W efekcie mamy do czynienia $\mathrm{z}$ sensem przeciwnym.

\section{Podsumowanie}

Podsumowując można stwierdzić, że przekład specjalistyczny wymaga od thumacza bardzo wysokich kwalifikacji. Tylko wszechstronne wykształcenie, znajomość języka specjalistycznego, języka źródłowego i docelowego umożliwia uniknięcie błędów stylistycznych oraz terminologicznych, co więcej bardzo dobra znajomość potocznego języka ojczystego i obcego jest konieczna aby uniknąc błędów gramatycznych, ortograficznych i interpunkyjnych. Znajomość zasad przekładu pozwala na eliminecję błędów, polegających na dodaniu lub opuszczeniu informacji. Te dwa ostatnie typy błędów bardzo często wynikają z braku korekty, polegającej na zczytaniu tekstu przekładu z tekstem oryginału. Podobnie jak błędy literowe i gramatyczne, które można wyeliminować, dokonując korekty językowej tekstu przekładu.

Tłumacz aktów normatywnych UE musi pamiętać, że są to teksty sformułowane w co najmniej dwóch językach specjalistycznych. Dlatego konieczne jest branie pod uwaę dwóch typów problemów thumaczeniowych. Kunz (1995:86), pisząc o tekstach UE zauważa, że „texts in all the official languages are supposed to be equivalent, at least in their legal effect. English and French are notorious for their near-but-not-exact correspondences, resulting in an enormous capacity for faux amis: the languages share much common vocabulary that has, unfortunately for translators and legislators, developed in different directions and covers different semantic areas. Words like «recommendation» and recommandation may be linguistic cognates, but they are certainly not semantic equivalents. Frequently, in order to understand what the English EC text means, one has to imagine what the original French must have been". Z punktu widzenia obywatela i sądu Rzezcpospolitej Polskiej, zatem tekst polski jest prawnie wiążący, co więcej sądy muszą orzekać na podstawie wersji w języku polskim nawet jeżeli są one obarczone błędem. Łatwo więc można sobie wyobrazić sytuację, w której zostaje wydany niesprawiedliwy wyrok, ponieważ polski „oryginał” zawierał błędy merytoryczne. $Z$ drugiej zaś strony, oprócz problemów związanych $\mathrm{z}$ przekładem prawniczym należy brać pod uwagę dziedzinę uregulowaną aktem normatywnym. Konsekwencje błędów tłumaczeniowych mogą być brzemienne w skutkach, zwłaszcza w przypadku tekstów prawniczych, medycznych i farmaceutycznych. Jeżeli chodzi o teksty prawnicze, błędy sprowadzają się najczęściej do ponoszenia strat finansowych. Natomiast, w przypadku tekstów medycznych i farmaceutyczncyh, błędy mogą skutkować uszczerbkiem na zdrowiu, a w skrajnych przypadkach mogą nawet prowadzić do utraty życia (gdy przykładowo lekarz poda niewłaściwą dawkę leku lub źle wykona operację). Dlatego też, szczególnie ważną kwestią jest uświadomienie thumaczom i adeptom przekładu, że praca thumacza tekstów specjalistycznych jest szczególnie odpowiedzialnym zadaniem i nie można do niego pochodzić lekkomyślnie czy też niefrasobliwie, tylko i wyłącznie jako do sposobu zarabiania pieniędzy. 


\section{Bibliografia}

Alcaraz, E., Hughes, B. 2002. Legal Translation Explained. Manchester: Svol. Jerome Publishing.

Bartmiński, J.1993. Odmiany i style języka - miarą bogactwa kultury. w: Encyklopedia Kultury Polskiej XX wieku. Wspótczesny język polski. Wrocław

Brostoff, J. Gamlin L. 1994. Alergia i nietolerancja pokarmowa. Kraków: Litera.

Brostoff, J. Gamlin L. 2000. Food allergies and intolerance: the complete guide to their identification and treatment. 3rd ed., Rocester: Healing Arts, cop.

Delisle, J. (et al., ed.). 1999. Translation Terminology. Amsterdam/Philadephia: John Benjamins Publishing Company.

Delisle, J. 1988. Translation: an interpretive approach. Ottawa/London: University of Ottawa Press.

Delisle, J. 2004. Terminologia tlumaczenia. Poznań: Wydawnictwo Naukowe UAM (thum. Teresa Tomaszkiewicz)

Dzierżanowska, H. 1990. Przektad tekstów nieliterackich. Warszawa: Państwowe Wydawnictwo Naukowe.

Faber, D., Hjort-Pedersen, M., Klinge, A. 1996/1997. Introduction to English Legal Language. BA Sproglinien.

Fisiak, J. 1961. An Early Middle English Reader. Łódź: Uniwersytet Łódzki.

Fisiak, J. 1961. Depluralizacja niektórych rzeczowników zapożyczonych z języka angielskiego. Język Polski 41, p. 138-9.

Fisiak, J. (ed.), t. 1 - 1973; t. 2 - 1974; t. 3 - 1975, t. 4 - 1976, Papers and Studies in Contrastive Linguistics. Poznań: Adam Mickiewicz University and Washington D.C.: Center for Applied Linguistics.

Grucza, F. 1978. Z problematyki błędów obcojęzycznych. Warszawa: Wydawnictwa Szkolne i Pedagogiczne.

Grucza, F. 1986. Problemy translatoryki $i$ dydaktyki translatorycznej. Warszawa: Wydawnictwa Uniwersytetu Warszawskiego.

Grucza, F. 1996. Wyodrębniane się, stan aktualny i perspektywy świata translacji oraz translatoryki. Ttumaczenie. Rzemiosto i sztuka, Jerzy Snopek (ed.). Warszawa: Węgierski Instytut Kultury.

Grucza, F. 1999. Translacja a kreatywność. w: Lingua Legis nr 7. 2-4.

Hejwowski, K. 2001. Źródła błędów w tłumaczeniu na język ojczysty. w: A. Kopczyński, U. Zaliwska-Okrutna (red.). Język rodzimy a język obcy. Komunikacja, przekład, dydaktyka. Warszawa: Wydawnictwo Uniwersytetu Warszawskiego.149-159.

Hejwowski, K. 2004. Kognitywno - komunikacyjna teoria przektadu. Warszawa: Wydawnictwo Naukowe PWN.

Joseph, J. E. 1995. Indeterminancy, Translation and the Law. Translation and the Law, M. Morris (ed.). Amsterdam/Philadelphia: John Benjamins Publishing Company, s. 13-36.

Karczewska, D. 2002. O błędach w tłumaczeniu. w: A. Kopczyński, U. Zaliwska-Okrutna (red.). Język rodzimy a język obcy. Komunikacja, przekład, dydaktyka. Warszawa: Wydawnictwa Uniwersytetu Warszawskiego. s. 129-148.

Kielar, B. Z., 2003. Rodzaje ekwiwalencji przekładowej tekstów specjalistycznych. w: B. Z., Kielar, S. Grucza (red.). Języki specjalistyczne. Lingwistyczna identyfikacja tekstów specjalistycznych. Warszawa: Katedra Języków Specjalistycznych Uniwersytetu Warszawskiego. s. 134-146.

Kielar, B. Z.1979. Styl a język prawny. Państwo i Prawo, z. 3, s. 134-135.

Kierzkowska, D. 2004. Kodeks ttumacza przysięgłego. Warszawa: TEPIS.

Kierzkowska, D. 2002. Ttumaczenie prawnicze. Warszawa: TEPIS.

Kłos P., Maternik E., Matulewska A., Piontek P. 2006. Translation or Non-Translation? Borrowings from English in the Polish Language of Biotechnology. w: Language, Communication and Information. Poznań: Wydawnictwo SORUS.

Kozłowska, Z. 2002. O błędach językowych w tekstach polskich przekładów. w: A. Kopczyński, U. Zaliwska-Okrutna (red.). Język rodzimy a jezzyk obcy. Komunikacja, przekład, dydaktyka. Warszawa: Wydawnictwo Uniwersytetu Warszawskiego. s. 137-149.

Kunz, K. 1995. Where the Devil Meets his Grandmother: Iceland and European Community Legislation. Translation and the Law. M. Morris (ed.). Amsterdam/Philadelphia: John Benjamins Publishing Company, s. 85-92.

Kurkowska, H., Skorupka, S. 2001. Stylistyka polska. Warszawa: Wydawnictwo Naukowe PWN.

Lewicki, A. M., Pajdzińska, A., Rejakowa, B. 1987. Z zagadnień frazeologii. Problemy leksykograficzne. Warszawa: Wydawnictwo Naukowe PWN.

Lukszyn, J. 1993. Tezaurus terminologii translatorycznej. Warszawa: Wydawnictwo Naukowe PWN.

Matulewska, A., Nowak, P. 2007. Problems in translation of EU legal texts into Polish. In: Court Interpreting and Legal Translation in the Enlarged Europe 2006. Warsaw: Translegis Publishing.

Nabokov, V. 2002. Wyktady o literaturze rosyjskiej. Warszawa: Warszawskie Wydawnictwo Literackie MUZA.S.A.

Nida, E. A. 1964. Toward a Science of Translating, with Special Reference to Principles and Procedures Involved in Bible Translating. Leiden, Holland: Brill.

Nida, E. A., Taber, C. 1969. The Theory and Practice of Bible Translation. Leiden.

Nie czytać po polsku. Gazeta Wyborcza. 10 styczeń 2005.

Nowak, P. 2006. Analiza błędów w przekładzie unijnych aktów normatywnych na przykładzie Council Regulation (EC) 1346/2000 of 29 May 2000 on Insolvency Proceedings. w: Investigationes Linguisticae 2006. Poznań: Adam Mickiewicz University, s. 171-195.

Pieńkos, J. 1999. Podstawy juryslingwistyki. Język w prawie - Prawo w języku. Warszawa: Muza S.A. Oficyna Prawnicza.

Pieńkos, J. 1999. Praecepta iuris. Łacina dla prawników. Terminy, paremie, wyrażenia w porzqdku systematycznym. Warszawa: Muza S.A.

Pieńkos, J. 2003. Podstawy przekladoznawstwa. Od teorii do praktyki. Kraków. Kantor Wydawniczy Zakamycze. 
Patrycja Kłos, Aleksandra Matulewska, Paulina Nowak-Korcz: Problemy przekładu specjalistycznego na przykładzie tekstów z dziedziny prawa, biologii, biotechnologii i medycyny.

Pisarska, A., Tomaszkiewicz, T. 1996. Współczesne tendencje przekładoznawcze: Poznań: Wydawnictwo Naukowe UAM.

Polański, M. 1999. Encyklopedia językoznawstwa ogólnego. Wrocław: Zakład Narodowy im. Ossolińskich.

Rayar, L. 1993. Translating Law: Method or Madness? International Forum of Legal Translation 1992. Proceedings. Warszawa: TEPIS, s. 62-71.

Rayar, L. 1999. Legal Translation: An Academic Specialism. Aspects of Legal Language and Legal Translation. J. Tomaszczyk (ed.). Łódź: Wydawnictwo Uniwersytetu Łódzkiego, s. 129-136.

Rayar, L. 1999. The Quality of Source Texts. Aspects of Legal Language and Legal Translation. J. Tomaszczyk (ed.). Łódź: Wydawnictwo Uniwersytetu Łódzkiego, s. 157-170.

Rozporządzenie prezesa rady ministrów z dnia 20 czerwca 2002r. w sprawie zasad techniki prawodawczej (Dz. U. z dnia 5 lipca 2002 r.).

Tytler, A. F. Lord Woodhouselee. 1813 (3). Essay on the Principles of Translation. Repr. London: J.M. Dent; New York: E.P. Dutton, n.d.

Ustawa z dnia 7 października 1999 r. o języku polskim. Dz.U. Nr 90, poz. 999.

Vermeer, H. J. 2001. Skopos and Commission in Translational Action. The Translation Studies Reader, L. Venuti and M. Baker (eds). London/New York: Routlege, s. 221-232.

Vinay, J.-P., Darbelnet J. 1958. Stylistique comparée du français et de l'anglais. Paris: Didier.

Vinay, J.-P., Darbelnet J. 2000. Methodology for Translation. The Translation Studies Reader, L. Venuti and M. Baker (eds). London/New York: Routledge, s. 84-93.

Voellangel, A. 1998. Jak nie tłumaczyć tekstów technicznych. Warszawa: TEPIS.

Wierzbicka, A., Wierzbicki, P. 1970. Praktyczna stylistyka. Warszawa: Wiedza Powszechna.

Wróblewski, B. 1948. Język prawny i prawniczy. Kraków.

Zieliński, M. 2006. Wykładnia prawa. Zasady, reguły, wskazówki. Warszawa: LexisNexis.

\section{Dyrektywy}

Commission Directive 2001/36/EC of 16 May 2001 amending Council Directive 91/414 http://eur-lex.europa.eu/LexUriServ/LexUriServ.do?uri=CELEX:32001L0036:EN:HTML

Directive 2000/54/EC of the European Parliament and of the Council of 18 September 2000 on the protection of workers from risks related to exposure to biological agents at work (seventh individual directive within the meaning of Article 16(1) of Directive 89/391/EEC) http://eur-lex.europa.eu/LexUriServ/LexUriServ.do?uri=CELEX:32000L0054:EN:HTML

Directive 2003/89/EC of the European Parliament and of the Council of 10 November 2003 amending Directive 2000/13/EC as regards indication of the ingredients present in foodstuffs (Text with EEA relevance) http://eur-lex.europa.eu/LexUriServ/LexUriServ.do?uri=CELEX:32003L0089:EN:HTML

Dyrektywa 2000/54/WE Parlamentu Europejskiego i Rady z dnia 18 września 2000 r. w sprawie ochrony pracowników przed ryzykiem związanym $\mathrm{z}$ narażeniem na działanie czynników biologicznych $\mathrm{w}$ miejscu pracy (siódma dyrektywa szczegółowa w rozumieniu art. 16 ust. 1 dyrektywy 89/391/EWG) http://eur-lex.europa.eu/LexUriServ/LexUriServ.do?uri=CELEX:32000L0054:PL:HTML

Dyrektywa 2003/89/WE Parlamentu Europejskiego i Rady z dnia 10 listopada 2003 r. zmieniająca dyrektywę 2000/13/WE w odniesieniu do oznaczania składników obecnych w środkach spożywczych (Tekst mający znaczenie dla EOG) http://eur-lex.europa.eu/LexUriServ/LexUriServ.do?uri=CELEX:32003L0089:PL:HTML

Dyrektywa Komisji 2001/36/WE z dnia 16 maja 2001 r. zmieniająca dyrektywę Rady 91/414/EWG dotycząca wprowadzania do obrotu środków ochrony roślin (Tekst mający znaczenie dla EOG) http://eur-lex.europa.eu/LexUriServ/LexUriServ.do?uri=CELEX:32001L0036:PL:HTML 